УДК 628.14:556.3(24):504.064(571.16)

\title{
МОНИТОРИНГ ХОЗЯЙСТВЕННОГО ОСВОЕНИЯ ТЕРРИТОРИИ В ПРЕДЕЛАХ ЗОН САНИТАРНОЙ ОХРАНЫ ПОДЗЕМНЫХ ВОДОЗАБОРОВ (НА ПРИМЕРЕ ПЕРВОЙ ЛИНИИ ТОМСКОГО ПОДЗЕМНОГО ВОДОЗАБОРА)
}

\author{
Попов Виктор Константинович 1 \\ Пасечник Елена Юрьевна1, \\ paseyu@yandex.ru \\ Чилингер Лилия Наримановна', \\ lilichilinger@gmail.com
}

\author{
Аврунев Евгений Ильич2, \\ avrynev_ei@ngs.ru \\ Редькина Вероника Игоревна', \\ V_red96@mail.ru \\ 1 Национальный исследовательский Томский политехнический университет, \\ Россия, 634050, г. Томск, пр. Ленина, 30. \\ 2 Сибирский государственный университет геосистем и технологий, \\ Россия, 630108, г. Новосибирск, ул. Плахотного, 10.
}

\begin{abstract}
Актуальность работы. Зоны санитарной охраны подземных водозаборов устанавливаются с целью защиты подземных вод эксплуатационных водоносных горизонтов от различных видов загрязнения на расчётный амортизационный срок его эксплуатации. По истечении этого периода или при существенном изменении интенсивности водоотбора производится переоценка запасов и, в случае необходимости, корректировка границ зоны санитарной охраны.

На основании проектной документации зоны санитарной охраны источников подземного питьевого водоснабжения вносятся в Единый государственный реестр недвижимости, причем определяемые расчетные границы согласовываются с иентром государственного санитарно-эпидемиологического надзора. Несмотря на то, что водозабор является стратегически важным объектом, необходимость учета в реестре границ появилась только в связи с вступлением в силу в 2007 г. Федерального закона № 221-Ф3. В настоящее время в отношении всех видов зон с особыми условиями использования территорий установлен срок внесения необходимых сведений в Единый государственный реестр недвижимости - до 1 января 2022 г. Таким образом, с момента расчета границ зон санитарной охраны до их установления и внесения сведений проходит длительный период времени, в течение которого зачастую может измениться антропогенная нагрузка (увеличивается площадь населенных пунктов, появляются новые объекты инженерной инфраструктуры) на участках с ограниченным режимом землепользования. В связи с этим возникает необходимость организации мониторинга хозяйственной деятельности в пределах зон санитарной охраны подземных водозаборов. На таких территориях необходимо оценивать и прогнозировать изменения компонентов природной среды под воздействием антропогенной нагрузки для получения достоверной информации о состоянии земель и способах обеспечения рационального землепользования.
\end{abstract}

Цель: раскрыть возможности мониторинга динамики хозяйственного освоения территории в пределах зон санитарной охраны первой очереди Томского подземного водозабора.

Методы: картометрические исследования на основе геоинформационных технологий, статистический и корреляционнорегрессионный анализы, геоинформационный анализ, метод ландшафтного анализа.

Результаты. Приводятся результаты исследований динамики и характера изменений антропогенной нагрузки в пределах зоны санитарной охраны центральной части первой очереди Томского подземного водозабора. Основу фактического материала составляют данные Федеральной службы государственной регистрации, кадастра и картографии по Томской области, банки пространственных данных internet-ресурса Esri maps, положенные в основу картометрического анализа лесопокрытых территорий и грании селитебных территорий. Выявлены тенденции к изменению площади различных видов ландшафртов и границ населенных пунктов в пределах района исследования. Ландшафтты данной территории подвергаются изменениям при развитии землепользования и водопользования. Селитебная нагрузка в 2018 г. относительно невелика, ее увеличение происходит, преимущественно, за счет индивидуального жилищного и дачного строительства, а не многоэтажной застройки. Выполнена оценка современной численности населения и дан прогноз её изменения на ближайшую перспективу. Выявлен прирост селитебных территорий по отдельным населенным пунктам.

Выводы. Установлено, что в пределах третьего пояса зоны санитарной охраны первой линии Томского подземного водозабора и на прилегающей территории за исследуемый период существенно возросла антропогенная нагрузка на природную среду за счет увеличения площади населенных пунктов. Рост произошел за счет освоения участков для индивидуального жилищного строительства, что может повлечь загрязнение водоносных горизонтов из-за неправильно оборудованных индивидуальных систем водоотведения. Показано, что вблизи существующей границы ЗСО активно ведется многоэтажная застройка, что может в целом оказать негативное влияние на состояние отдельных элементов ландшасрта, в том числе и на подземные воды.

Таким образом, на примере Томского подземного водозабора сделан главный вывод о том, что необходима организация и проведение мониторинга хозяйственного освоения территории в пределах зон санитарной охраны подземных водозаборов. 
Требуется отрегулировать процедурные вопросы внесения сведений в Единый государственный реестр недвижимости в кратчайшие сроки после выполнения работ по оценке и переоценке запасов подземных вод для установления границ зон санитарной охраны и вступления в юридическую силу ограничений хозяйственной деятельности на данной территории.

Ключевые слова:

Зона санитарной охраны, антропогенное воздействие, геоинформационные технологии, мониторинг, ландшафт, численность населения.

\section{Введение}

В процессе развития люди приходят к осознанию того, что территория проживания может и должна использоваться целиком и полностью, включая все ресурсы, и, в первую очередь, возобновляемые - водные и земельные. Последствием такого взаимоотношения человека и природы является непоправимый натиск индустриализации и урбанизации [1], направленный на все компоненты природной среды.

Зачастую складывается такая ситуация, когда в пределы границ зоны санитарной охраны (ЗСО) водозаборов могут попадать территории населенных пунктов, которые существовали на данной территории до введения водозабора в эксплуатацию. Со временем населенные пункты начинают разрастаться, что сказывается на увеличении антропогенной нагрузки [2] на все компоненты геологической среды. Во-первых, изменяется сам ландшафт: застраиваются поля, вырубаются деревья, прокладываются асфальтовые дороги, что влечет за собой изменение водного режима. Во-вторых, возрастают потребляемые населением ресурсы, соответственно, возникают проблемы с их утилизацией - организацией систем водоотведения и вывоза бытовых отходов. Если населенные пункты не оборудованы централизованной системой водоотведения, возникают проблемы с загрязнением подземных вод. Даже если дома оборудованы септиками, далеко не все они выполнены герметично, и, по мере заполнения, зачастую стоки сбрасываются на рельеф, а не вывозятся на очистные сооружения.

Размеры поясов ЗСО водозаборов из подземных источников водоснабжения устанавливаются в соответствии с СанПиН 2.1.4.1110-02 [3]. Второй и третий пояса (пояса ограничений) предназначены для предупреждения возникновения загрязнения подземных вод на данной территории. В случаях строительства с нарушением почвенного покрова на территории с ограниченным использованием необходимо согласование с центром государственного санитарноэпидемиологического надзора.

В этой связи вопрос мониторинга хозяйственной деятельности в пределах ЗСО подземных водозаборов является чрезвычайно актуальным. Ключевым фактором в оценке современного геоэкологического состояния территории является определение антропогенной нагрузки на различные компоненты природной среды и в целом на природные комплексы, причем для значительных по площади территорий приоритетное внимание уделяется качественной оценке характера антропогенной нагрузки, а не её количественным показателям [4], роль которых возрастает при увеличении детальности исследований.
Экологическое и санитарно-гигиеническое состояние земель территории Обь-Томского междуречья (ОТМ) имеет для г. Томска огромное значение, т. к. здесь расположен Томский подземный водозабор, снабжающий жителей города с 1973 г. качественной питьевой водой. Данная территория является привлекательной для развития жилой застройки из-за близости к административному центру города и в последние годы все активнее осваивается, хотя на этапе проектирования и создания водозабора из-за недостаточной защищенности подземных вод территорию ОТМ планировали использовать только в целях рекреации и для нужд сельского хозяйства.

\section{Томский подземный водозабор}

Томский подземный водозабор относится к водозаборам линейного типа и состоит из 198 эксплуатационных скважин. В настоящее время в работе находятся 95 скважин в режиме обычной нагрузки, 14 из которых относятся к контрольным для забора проб на качество подаваемой воды.

На территории Обь-Томского междуречья последняя переоценка запасов подземных вод на участке Томского подземного водозабора с учетом потребностей областного центра в воде и существующей антропогенной нагрузки была проведена в 2003 г. сроком на 27,4 года и рассчитаны границы зоны санитарной охраны.

Объектом нашего исследования (рис. 1) является территория третьего пояса $3 \mathrm{CO} \mathrm{первой} \mathrm{очереди} \mathrm{водо-}$ забора (скважины 1э-69э), которая была запущена в эксплуатацию 13 декабря 1973 г. [5]. Полностью строительство первой очереди было завершено в октябре 1974 г. [6].

Сведения о границах 3 СО в Единый государственный реестр недвижимости внесены только в феврале 2014 г. За это время существенно расширились границы населенных пунктов в пределах поясов зоны санитарной охраны и усилилась антропогенная нагрузка на ландшафты в целом и на подземные воды. Таким образом, возникла проблема неполного соответствия характера техногенной нагрузки, учтённой при расчёте границ зоны санитарной охраны, и её современных масштабов. Отмеченное противоречие может быть устранено организацией мониторинга хозяйственной деятельности для оперативного уточнения сведений, вносимых в Единый государственный реестр недвижимости.

Площадь территории ЗСО Томского подземного водозабора достигает 26000 гектар. Площадь исследуемой территории в пределах третьего пояса первой очереди составляет 12359 гектар (рис. 1) 


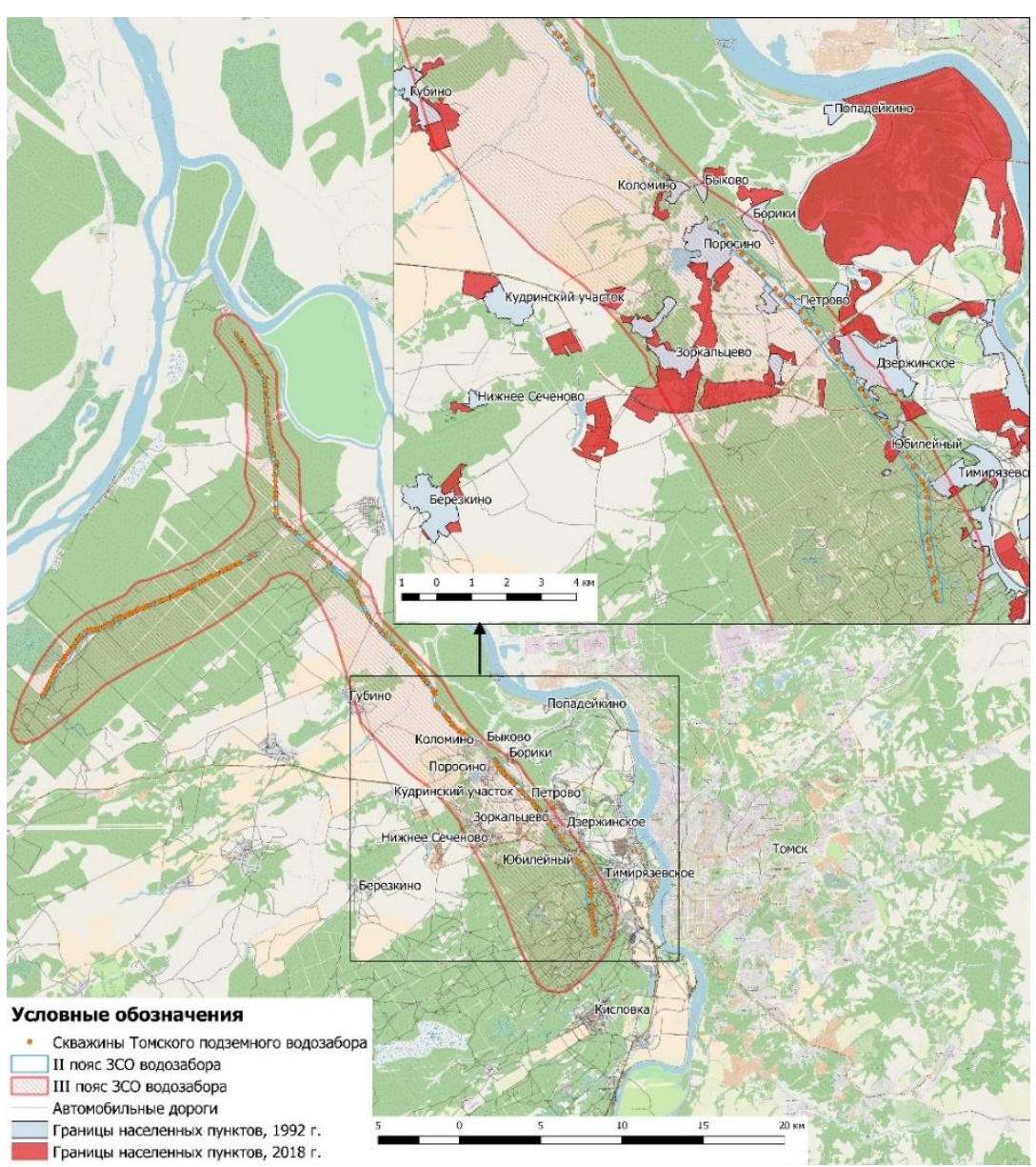

Рис. 1. Схема расположения территории исследования

Fig. 1. Location map of the research area

Выбор территории для проведения исследовательских работ обусловлен двумя основными факторами:

- близость населенных пунктов к городу Томску (административному центру Томской области) и максимальная на территории Обь-Томского междуречья интенсивность хозяйственного освоения;

- слабая степень защищенности эксплуатационного водоносного горизонта на участке водозаборных скважин № 24 и 69, где не исключена возможность поступления загрязняющих веществ с поверхности через гидрогеологические окна [2].

\section{Исходные материалы и методы исследования}

Исследование хозяйственной деятельности на выбранной территории авторы проводили путем анализа использования земельных ресурсов с 1992 г. по настоящее время. Для оценки и прогноза численности населения в работе применялся системный, статистический и корреляционно-регрессионный анализы. При оценке динамики изменения селитебной территории использовался метод ландшафтного анализа и системного картографирования, картометрические исследования при помощи геоинформационных технологий.

При выполнении работы исходными материалами послужили планшеты масштаба 1:10000 (выпуск 1992 г. (обновление не производилось), являющиеся дежурной картой Администрации Томского района, генеральные планы администраций города Томска и сельских поселений, спутниковые карты internetpecypca Esri maps, кадастровые планы территории Федеральной службы государственной регистрации, кадастра и картографии по Томской области, сведения лесохозяйственного регламента Тимирязевского лесничества Томской области. Расчеты по пространственному анализу динамики площадей выполнялись в геоинформационной системе Qgis.

Для расчета и прогноза численности населения использовались данные Росстата, проектные декларации и разрешения на ввод в эксплуатацию объектов микрорайона «Северный парк». Статистическая обработка нами проводилась на период с 2002 по 2040 гг.с помощью функциональных возможностей электронных таблиц Microsoft Excel путем построения диаграмм с добавлением линии тренда.

\section{Мониторинг численности населения}

По результатам анализа генеральных планов и правил землепользования и застройки сельских поселений территории в границах Обь-Томского междуречья разработана карта-схема категорий земель (рис. 2). На ней обозначены фактические границы населенных пунктов, а также земли, переведенные в категорию населенных пунктов, но не входящие в их административные границы. 


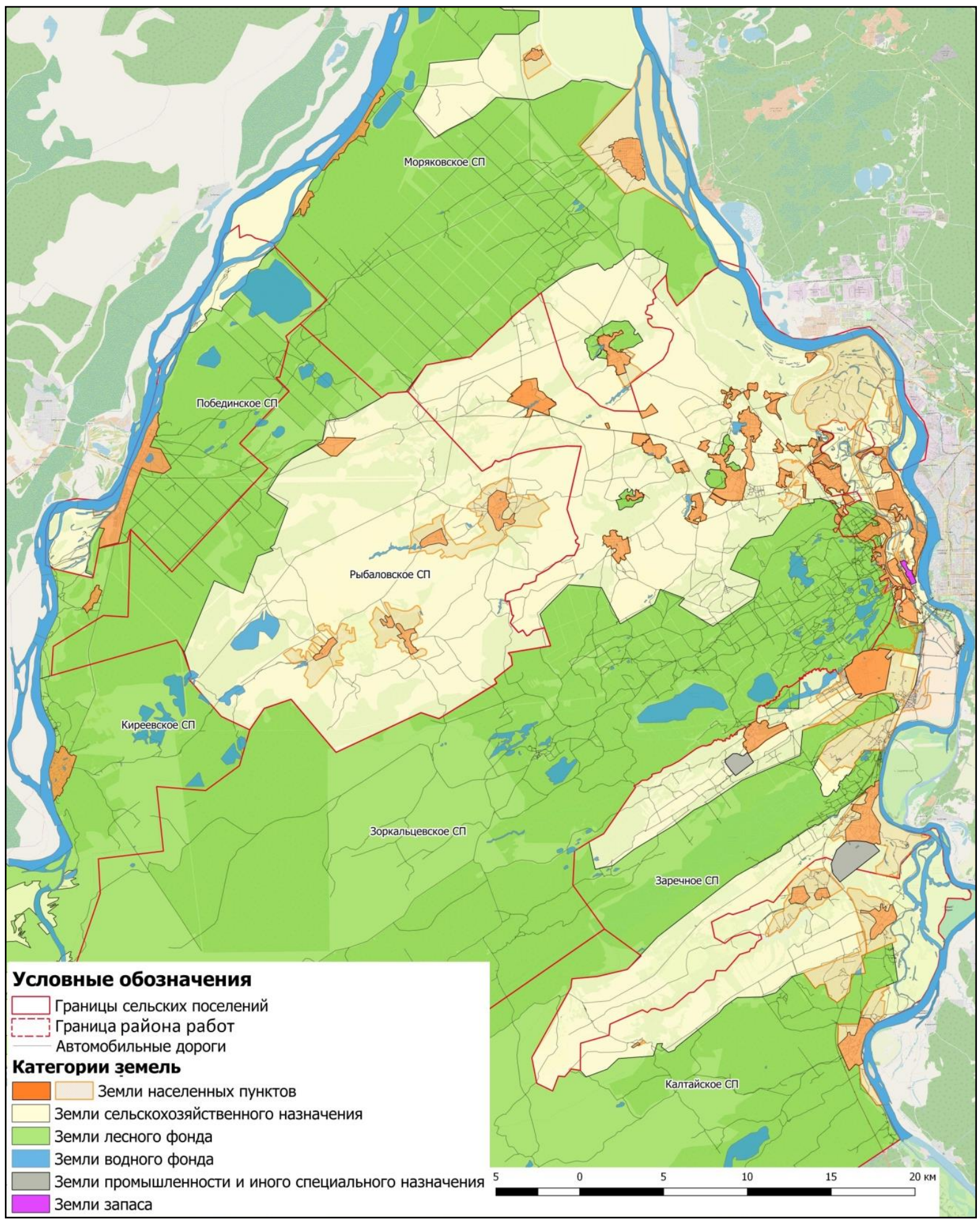

Pис. 2. Карта-схема категорий земель на территории Обь-Томского междуречья

Fig. 2. Map of land categories on the territory of the Ob-Tomsk interfluve

Общая площадь земельного фонда Обь-Томского междуречья составляет 356,7 тыс. га (табл. 1). Основную долю площади занимают земли лесного фонда и земли сельскохозяйственного назначения, которые составляют 63,7 и $22,7 \%$, соответственно (рис. 3 ).

В табл. 2 приведены сведения об изменении численности населения на территории второго и третьего поясов зоны санитарной охраны в пределах участка первой очереди Томского подземного водозабора. Оценка динамики численности населения построена с использованием данных Росстата о количестве жителей, прописанных на селитебных территориях в условиях малоэтажной застройки $[7,8]$. На территориях отдельных населённых пунктов авторами показана неравномерность распределения плотности населения (табл. 2, рис. 4). 
Таблица 1. Площуади отдельных категорий земель на территории Обь-Томского междуречья

Table 1. Area of certain categories of land in the territory of the Ob-Tomsk interfluve

\begin{tabular}{|c|c|}
\hline $\begin{array}{c}\text { Категории земель } \\
\text { Land categories } \\
\end{array}$ & $\begin{array}{c}\text { Площадь, га } \\
\text { Area, ha }\end{array}$ \\
\hline Земли лесного фонда/Forest fund lands & 227398,4 \\
\hline $\begin{array}{l}\text { Земли сельскохозяйственного назначения } \\
\text { Agricultural land }\end{array}$ & 81053,2 \\
\hline Земли водного фонда/Water fund lands & 29300,0 \\
\hline $\begin{array}{l}\text { Земли населенных пунктов } \\
\text { Land of settlements }\end{array}$ & 18418,8 \\
\hline Земли промышленности/Industrial lands & 534,0 \\
\hline Земли запаса/Reserve land & 45,7 \\
\hline $\begin{array}{l}\text { Суммарно по всем категориям } \\
\text { In total in all categories }\end{array}$ & 356750,1 \\
\hline
\end{tabular}

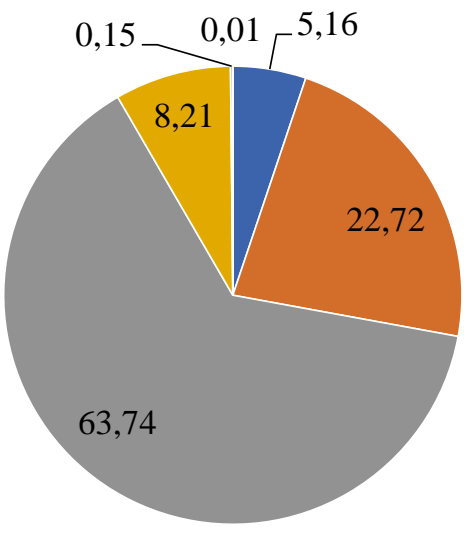

Согласно графику, показанному на рис. 4, наблюдается резкое повышение численности населения за период с 2002 по 2008 гг. В это время во всех населенных пунктах активно ведется строительство частных домов и коттеджей. В последующий период (с 2008 по 2015 гг.) наблюдается незначительный стабильный прирост численности населения на 11,5\%. Если рассматривать населенные пункты по отдельности, то для них характерны одинаковые тенденции изменения численности населения. Село Дзержинское было включено в состав муниципального образования «город Томск» в ноябре 2004 г. Возможно, именно по этой причине в 2002-2008 гг. произошло резкое увеличение численности населения на 741 человека (за счет присоединения новых территорий).

\section{— Земли населенных пунктов \\ • Земли сельскохозяйственного назначения \\ - Земли лесного фонда \\ — Земли водного фонда \\ • Земли промышленности и иного специального назначения}

• Земли запаса

Рис. 3. Относительная доля различных видов землепользования в общей площчади земельного фонда территории Обь-Томского междуречья, \%

Fig. 3. Relative share of different types of land use in the total land area of the territory of the Ob-Tomsk interfluve, \%

Таблица 2. Численность жителей населенных пунктов на центральном участке Томского подземного водозабора Table 2. Population of inhabitants of settlements in the central part of the Tomsk underground water intake

\begin{tabular}{|c|c|c|c|c|c|c|c|c|c|}
\hline \multirow{2}{*}{$\begin{array}{c}\text { Населенный пункт } \\
\text { Locality (village) } \\
\end{array}$} & \multicolumn{9}{|c|}{ Год/Year } \\
\hline & 2002 & 2008 & 2009 & 2010 & 2011 & 2012 & 2013 & 2014 & 2015 \\
\hline $\begin{array}{l}\text { c. Тимирязевское } \\
\text { Timiryazevskoe }\end{array}$ & 6211 & 6468 & 6466 & 6406 & 6421 & 6412 & 6506 & 6480 & 6434 \\
\hline $\begin{array}{l}\text { c. Дзержинское } \\
\text { Dzerzhinskoe }\end{array}$ & 2223 & 2964 & 2941 & 2861 & 2774 & 2898 & 2943 & 2920 & 2914 \\
\hline $\begin{array}{l}\text { c. Зоркальцево } \\
\text { Zorkaltsevo }\end{array}$ & 1170 & 1228 & 1268 & 1245 & 1250 & 1236 & 1232 & 1265 & 1273 \\
\hline $\begin{array}{l}\text { д. Борики } \\
\text { Boriki }\end{array}$ & 406 & 427 & 438 & 440 & 441 & 434 & 435 & 406 & 427 \\
\hline $\begin{array}{l}\text { д. Быково } \\
\text { Bykovo }\end{array}$ & 2 & 3 & 4 & 4 & 7 & 9 & 9 & 21 & 24 \\
\hline $\begin{array}{l}\text { д. Коломино } \\
\text { Kolomino }\end{array}$ & 27 & 36 & 37 & 55 & 55 & 67 & 71 & 74 & 76 \\
\hline $\begin{array}{l}\text { д. Кудринский Участок } \\
\text { Kudrinskiy Uchastok }\end{array}$ & 329 & 339 & 341 & 382 & 382 & 385 & 388 & 400 & 394 \\
\hline $\begin{array}{l}\text { д. Петрово } \\
\text { Petrovo }\end{array}$ & 553 & 561 & 549 & 495 & 495 & 497 & 505 & 532 & 536 \\
\hline $\begin{array}{l}\text { д. Петровский Участок } \\
\text { Petrovskiy Uchastok }\end{array}$ & 20 & 18 & 18 & 75 & 75 & 84 & 88 & 95 & 112 \\
\hline $\begin{array}{l}\text { д. Поросино } \\
\text { Porosino }\end{array}$ & 917 & 926 & 933 & 921 & 924 & 930 & 963 & 987 & 977 \\
\hline $\begin{array}{l}\text { пос. Кайдаловка } \\
\text { Kaydalovka }\end{array}$ & 5 & 9 & 9 & 9 & 18 & 18 & 18 & 29 & 30 \\
\hline $\begin{array}{l}\text { д. Губино } \\
\text { Gubino }\end{array}$ & 475 & 447 & 449 & 554 & 556 & 555 & 558 & 558 & 559 \\
\hline $\begin{array}{l}\text { Итого } \\
\text { In total }\end{array}$ & 12338 & 13426 & 13453 & 13447 & 13398 & 13525 & 13716 & 13767 & 13756 \\
\hline
\end{tabular}




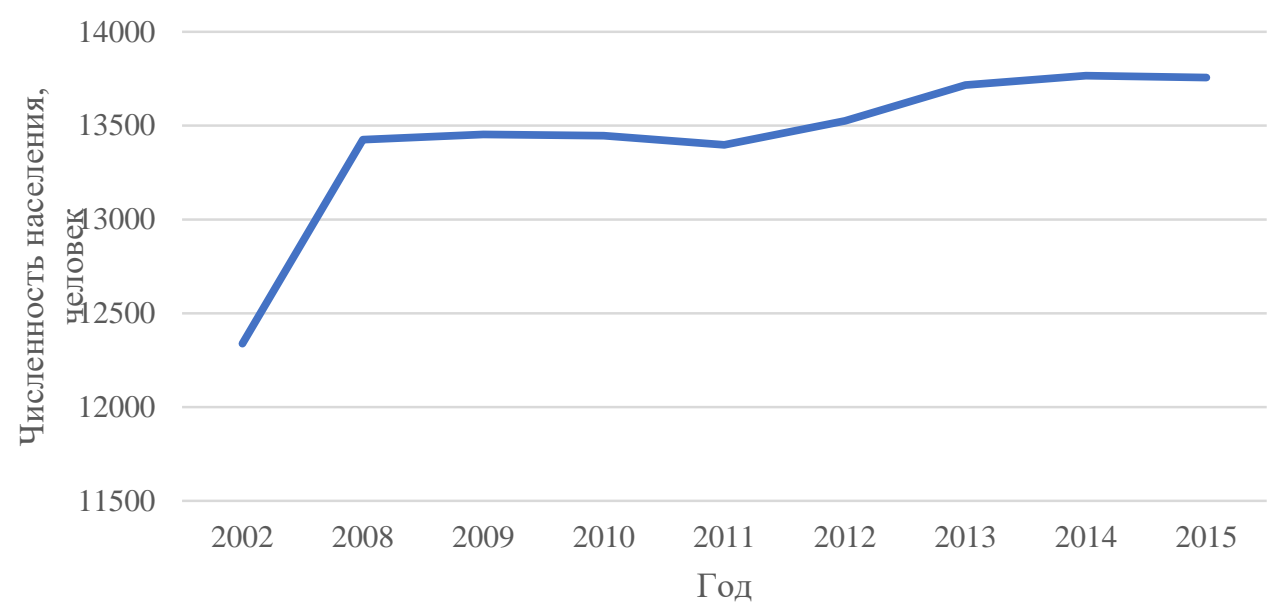

Pис. 4. График изменения общей численности жителей населенных пунктов на иентральном участке Томского подземного водозабора за 2002-2015 г2. (по табл. 2)

Fig. 4. Graph of changes in the total population of settlements in the central part of the Tomsk underground water intake for 2002-2015 (according to table 2)

Для анализа перспектив дальнейшего изменения роста численности населения был получен прогноз на основе тренда и колебаний динамического ряда (по методу экстраполяции в рядах динамики). Одним из наиболее распространенных способов экстраполяции рядов динамики является их выравнивание на основе аналитических зависимостей. В основе этого способа лежит подбор функции, отображающей общую зако- номерность изменения. Зная вид функции, описывающей тенденцию изменения, и подставляя в нее известные значения переменной X (год прогнозирования) за пределами динамического ряда, можно рассчитать теоретический уровень искомого результата с определенной степенью вероятности (рис. 5).

Нами был выполнен общий прогноз численности населения на 2030 и 2040 гг.

\section{Общая численность населения}

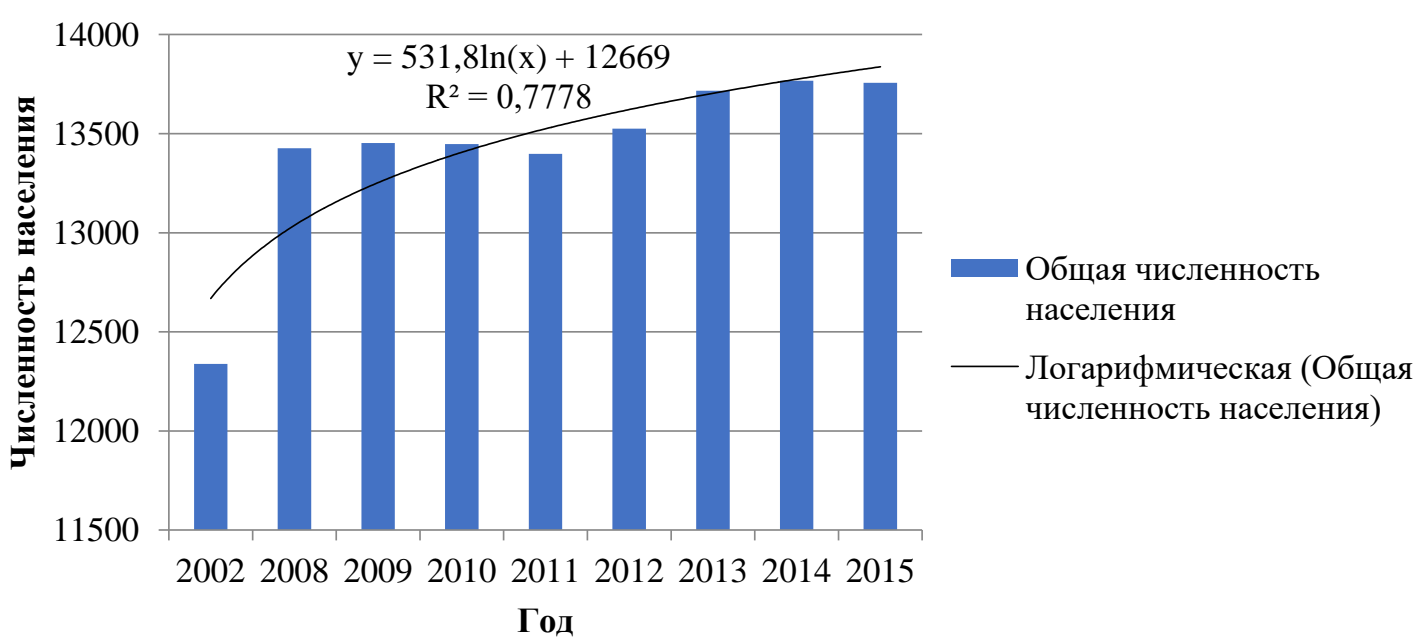

Рис. 5. Вид функиии для прогноза численности населения в рассматриваемых населенных пунктах методом экстраполячии

Fig. 5. Type of a function for population projection in the populated areas under consideration by extrapolation

Для установления точности прогноза был рассчитан доверительный интервал [9]:

$$
Y_{\text {д }}=\mathrm{Y}_{\mathrm{T}} \pm \mathrm{M}
$$

и интервальная оценка:

$$
\mathrm{M}=G * C,
$$

где $G$ - критерий Стьюдента; $C$ - ошибка метода.

Расчет ошибки производился по формуле:

$$
C=\frac{\sum \sqrt{\left(Y_{\phi}-Y_{\mathrm{T}}\right)^{2}}}{n-p-1},
$$

где $Y_{\phi}$ - фактический уровень показателя; $Y_{\mathrm{T}}$ - теоретический уровень показателя; $n$ - количество наблюдений; $p$ - количество параметров функции $(\mathrm{A}, \mathrm{B})$.

Теоретический уровень населения был определен с использованием функции, подобранной методом экстраполяции (рис. 5). 
Согласно выполненным расчетам, ошибка метода получилась равной 430 человек, что составляет $3,1 \%$ от общей численности населения.

Подобранная функция для прогноза численности населения методом экстраполяции имеет полиномиальный логарифмический вид $Y=A+B \ln (x)$. Параметры функции равны: $A=12669 ; B=531,8 ; X$ - индекс года прогнозирования:

- для первого периода прогнозирования в 15 лет (для 2030 г.) индекс будет равен 29;

- для второго периода прогнозирования в 25 лет (для 2040 г.) индекс будет равен 39.

$$
\begin{aligned}
& Y_{2030}=12669+531,8 \ln (29)=14460, \\
& Y_{2040}=12669+531,8 \ln (39)=14617 .
\end{aligned}
$$

Анализ показал, что при сложившихся тенденциях изменения численности населения в пределах зоны санитарной охраны первой очереди Томского подземного водозабора теоретическое значение данного показателя к 2030 г. может составить 14460 человек, а к 2040 г. достигнет 14617 человек. Доверительный интервал, согласно критерию Стьюдента и рассчитанной ошибки метода [9], составит 881 (на 2030 г.) и 869 (на 2040 г.). Следовательно, фактическое значение численности населения будет находиться в интервале:
- $\quad$ на первый период прогнозирования (2030 г.) - от 13579 до 15341 человек;

- на второй период прогнозирования (2040 г.) - от 12887 до 15487 человек.

Такой прогноз можно использовать, если развитие населенных пунктов будет происходить на селитебных территориях в условиях малоэтажной застройки.

Однако в последние годы на левом берегу реки Томи развивается многоэтажная жилая застройка. Площадь территории, занимаемой микрорайоном «Северный парк», в настоящее время составляет 35,5 га (рис. 6). На данной территории, согласно проектным декларациям и разрешениям на ввод в эксплуатацию объектов, расположено:

- 19 домов до 5 этажей (2077 квартир):

- однокомнатных - 1040;

- двухкомнатных - 793;

- трехкомнатных -244 .

- дом 11-15 этажей (158 квартир);

- дом 8 этажей (76 квартир), не считая объектов социального назначения.

Кроме того, на территории мкр. «Северный парк» расположено 12 земельных участков для малоэтажной застройки и один большой, еще не разделенный земельный массив (примерно на 12 земельных участков).

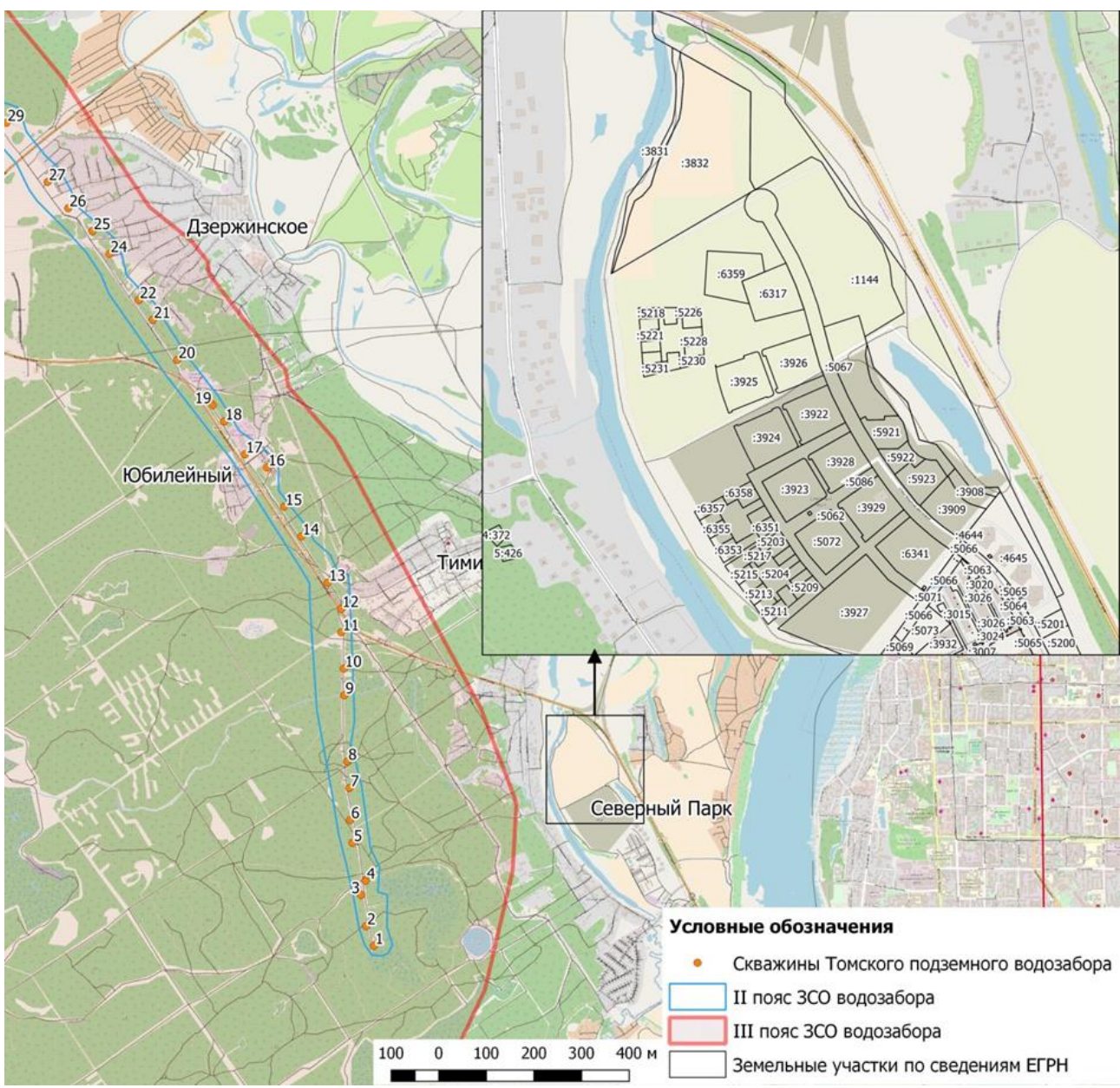

Рис. 6. Расположение района многоэтажной застройки (Северный парк) на территории ОТМ

Fig. 6. Location of the multi-storey building area (Severny park) in the Ob-Tom interfluve (OTI) territory 
Можно предположить, что численность мкр. «Северный парк» составит 9340 человек (2311 квартир и 24 земельных участка, при условии, что средний состав семьи 4 человека).

Согласно сведениям публичной кадастровой карты и данным кадастровых планов территории, вблизи мкр. «Северный парк» находятся еще 3 земельных участка, общей площадь которых составляет 163,3 га с видом разрешенного использования «для размещения объектов, характерных для населенных пунктов», которые были переведены из земель сельскохозяйственного назначения в земли населенных пунктов.

Если предположить, что данные участки будут застраиваться аналогично с проектной документацией мкр. «Северный парк», и рассчитать количество семей, получается:

1. 163,3 га $/ 35,5$ га $=4,6$ микрорайонов.

2. 4,6 микрорайонов * (2311 квартир+24 земельных участка) $=10741$ семья [10].

Если средняя семья состоит из 4 человек, то численность Левобережья увеличится более чем на 42 тысячи человек.

Так как территория мкр. «Северный парк» находится в непосредственной близости от третьего пояса ЗСО Томского подземного водозабора, необходимо обращать особое внимание на создание мероприятий по недопущению негативного влияния на окружающую природную среду.

\section{Анализ динамики площадей селитебных территорий}

Анализ площадей территорий, занятых населенными пунктами в контурах третьего пояса ЗСО первой линии Томского подземного водозабора с использованием архивных картографических материалов (планшетов) за 1992 г., и сведений пространственных данных Esri maps $[11,12]$ за 2018 г. позволил составить карту динамики роста границ населенных пунктов (рис. 7).

За период с 1992 по 2018 гг. территории, занятые населенными пунктами, увеличились на 1317,3 га или чуть больше, чем в два раза. Так, их площадь в 2018 г. достигла 2415,7 га, для сравнения в 1992 г. она составляла 1098,4 га. Особое внимание необходимо обратить на то, что прирост площади населенных пунктов в пределах зон санитарной охраны приходится на индивидуальное жилищное и дачное строительство, а не на многоквартирные дома. С помощью программного комплекса Quantum GIS (QGIS) выполнена оценка прироста селитебной территории [13] по отдельным населенным пунктам (табл. 3). Результат оценки изменения границ населенных пунктов получен путем совмещения кадастровых планов территории и современных очертаний населенных пунктов, оцифрованных по космическими снимкам.

Следует отметить, что границы некоторых населенных пунктов увеличились в несколько раз (с. Зоркальцево; п. Кайдаловка) ввиду строительства новых микрорайонов, которые располагаются в окрестностях сел и поселков (ТСН «Зоркальцевские Усадьбы», ДНП «Слобода Вольная», ДНТ «Солнечный Плюс»; мкр. «Снегири», мкр. «Серебряный Бор»).
Таблица 3. Прирост площуадей селитебных территорий в районе центральной части Томского подземного водозабора (за период с 1992 по 2018 г2.)

Table 3. Increase in the territory of residential areas in the central part of the Tomsk underground water intake (for the period from 1992 to 2018)

\begin{tabular}{|c|c|c|}
\hline \multirow{2}{*}{$\begin{array}{l}\text { Населенный пункт } \\
\text { Locality (village) }\end{array}$} & \multicolumn{2}{|c|}{ Площадь, га/Area, ha } \\
\hline & 1992 & 2018 \\
\hline $\begin{array}{l}\text { с. Тимирязевское } \\
\text { Timiryazevskoe }\end{array}$ & 254 & 345,3 \\
\hline $\begin{array}{l}\text { c. Дзержинское } \\
\text { Dzerzhinskoe }\end{array}$ & 224,5 & 359,7 \\
\hline $\begin{array}{l}\text { с. Зоркальцево } \\
\text { Zorkalrsevo }\end{array}$ & 120,8 & 587,9 \\
\hline $\begin{array}{l}\text { д. Борики } \\
\text { Boriki }\end{array}$ & 45,6 & 87,5 \\
\hline $\begin{array}{c}\text { д. Быково } \\
\text { Bykovo }\end{array}$ & 13,1 & 37,6 \\
\hline $\begin{array}{l}\text { д. Коломино } \\
\text { Kolomino }\end{array}$ & 24,1 & 52,3 \\
\hline $\begin{array}{c}\text { д. Кудринский Участок } \\
\text { Kudrinskiy Uchastok }\end{array}$ & 99,1 & 200,4 \\
\hline $\begin{array}{l}\text { д. Петрово } \\
\text { Petrovo }\end{array}$ & 71,6 & 71,6 \\
\hline $\begin{array}{l}\text { д. Петровский Участок } \\
\text { Petrovskiy Uchastok }\end{array}$ & 23,7 & 166,6 \\
\hline $\begin{array}{l}\text { д. Поросино } \\
\text { Porosino }\end{array}$ & 124,8 & 130,8 \\
\hline $\begin{array}{c}\text { пос. Кайдаловка } \\
\text { Kajdalovka }\end{array}$ & 3,8 & 166,5 \\
\hline $\begin{array}{c}\text { д. Губино } \\
\text { Gybino }\end{array}$ & 93,3 & 209,5 \\
\hline $\begin{array}{l}\text { Итого } \\
\text { In total }\end{array}$ & 1098,4 & 2415,7 \\
\hline
\end{tabular}

Динамика изменения площади селитебной территории в центральной части Томского подземного водозабора за период с 1992 по 2018 гг. представлена на рис. 8.

Большинство земель, на которых располагаются новые микрорайоны, - это паевые земли, которые были переданы гражданам бесплатно в общедолевую собственность в начале 1990-х гг. и предназначались для сельскохозяйственного использования. Эти земли были скуплены предпринимателями, которые перевели их в земли населенных пунктов согласно Федеральному закону № 172-Ф3 [14].

Большинство людей используют исследуемую территорию для временного (сезонного) проживания и прописаны в городских квартирах, именно поэтому в сравнении с незначительным увеличением численности населения площадь населенных пунктов увеличилась существенно.

\section{Оценка антропогенной нагрузки} на исследуемой территории

Экологический фонд территории представляет собой различные природные и техногенные ландшафты, которые имеют свой предел устойчивости $[15,16]$. Оценка состояния структуры землепользования исследуемой территории проведена на основе метода экспертной оценки [17] и классификации [15] по использованию земельного фонда (рис. 9). 


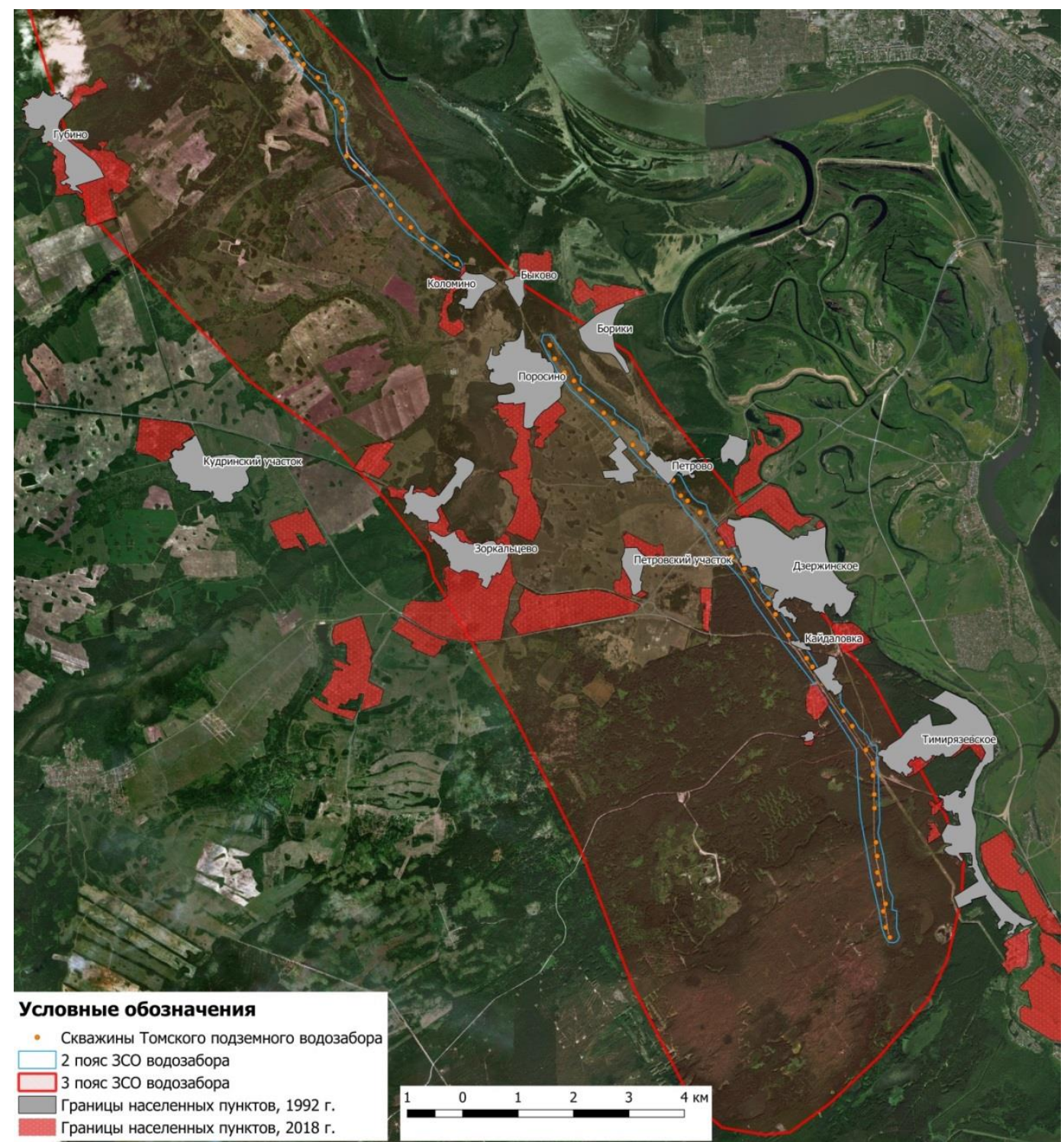

Pис. 7. Карта-схема роста площадей селитебных территорий в районе первой очереди Томского подземного водозабора Fig. 7. Sketch map of residential territory in the areas of the first stage of the Tomsk underground water intake

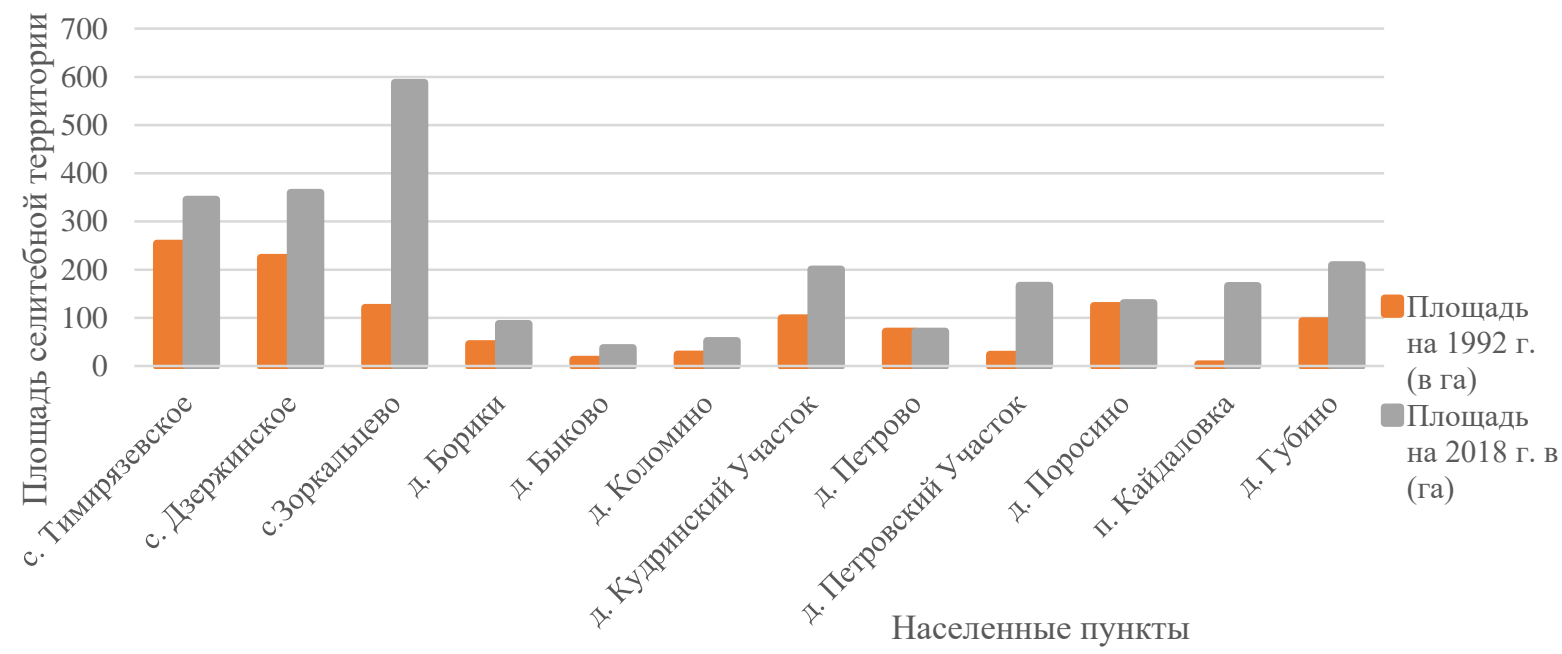

Pис. 8. Диаграмма изменения площадей селитебных территорий в пределах третьего пояса ЗСО первой линии Томского подземного водозабора (за период с 1992 по 2018 гг.)

Fig. 8. Diagram of change in the residential areas within the third sanitary protection zone of Tomsk underground water intake first line (for the period from 1992 to 2018) 


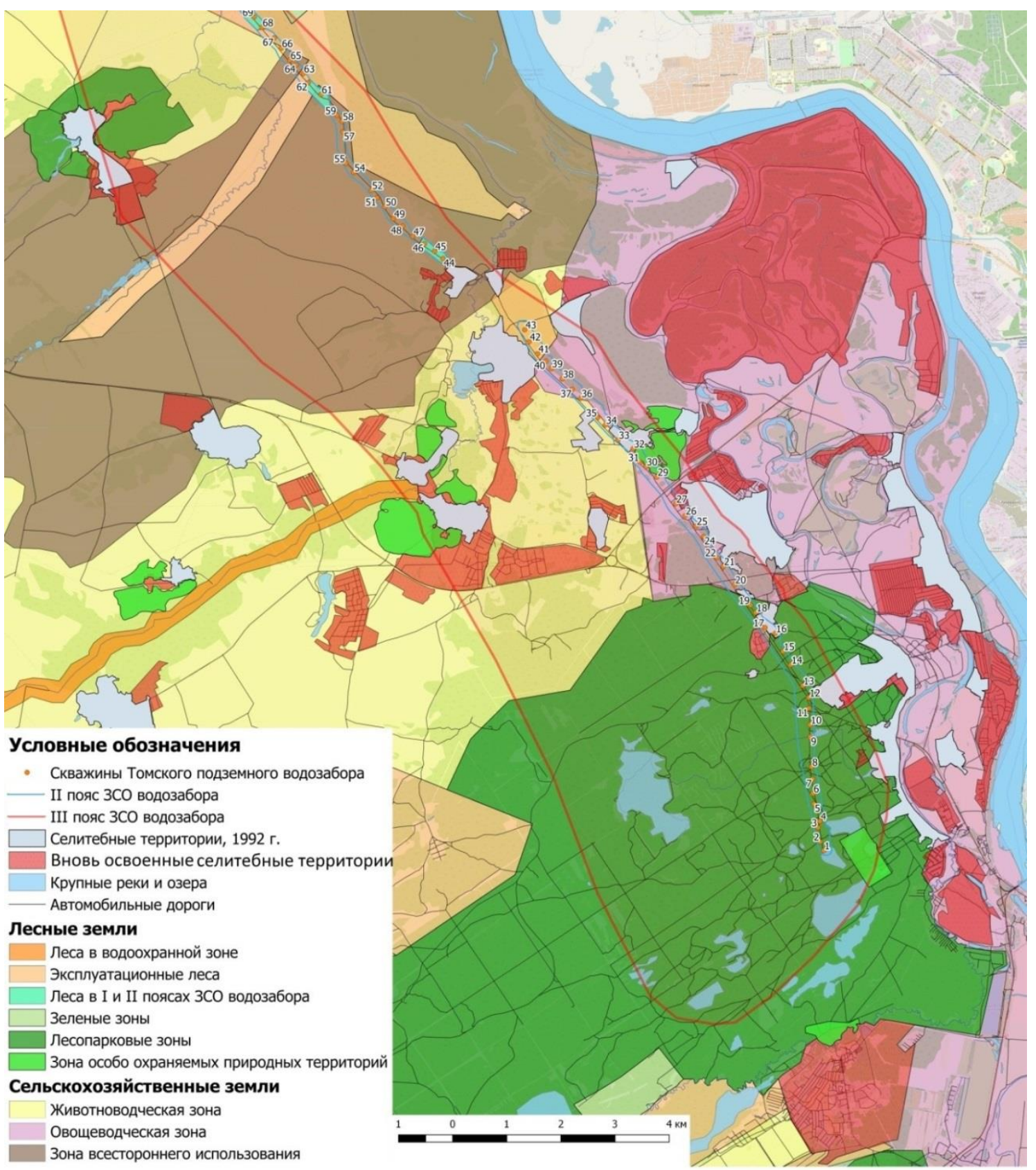

Pис. 9. Карта-схема роста селитебной территории с учетом ландмафтов

Fig. 9. Sketch map of residential area grown dynamic in consideration of landscapes

Для территории в пределах ЗСО первой очереди Томского подземного водозабора был рассчитан эколого-хозяйственный баланс (табл. 4). Представленные виды ландшафтов были ранжированы по степеням антропогенной нагрузки экспертным путем [18-23]. Было установлено, что наибольшую антропогенную нагрузку [24, 25] оказывают селитебные территории, а наименьшую - природоохранные земли и неиспользуемые земли (запаса), которые от общей площади составляют 12,3 и $1,1 \%$, соответственно.

Для изучения нагрузки антропогенной деятельности на земельный фонд проведена оценка экологохозяйственного баланса территории [15].

На основании этой методики был рассчитан коэффициент абсолютной напряженности $\mathrm{K}_{\mathrm{a}}$, характери- зующий отношение сильно нарушенных площадей (развитие селитебной территорий влечет за собой не только деятельность промышленных предприятий, но и загруженность автотранспортом) и земель мало нарушенных или не используемых.

Согласно методике Б.И. Кочурова [15] установлено, что чем больше коэффициент абсолютной напряженности $K_{a}$, тем больше территория перегружена хозяйственной деятельностью. При более высоких значениях коэффициента необходимо создание природоохранных территорий для поддержания восстановительного потенциала природной среды. В процессе оценки эколого-хозяйственного баланса территории принимают, что чем меньше значение коэффициента $\mathrm{K}_{\mathrm{a}}$, тем лучше состояние окружающей среды. 
Таблица 4. Ранжирование ландшафтов центральной части Томского подземного водозабора по степеням антропогенной нагрузки

Table 4. Grading of Tomsk central part of the underground water intake by degrees of anthropogenic load

\begin{tabular}{|c|c|c|c|}
\hline $\begin{array}{c}\text { Степень антропогенной нагрузки } \\
\text { Degree of anthropogenic load }\end{array}$ & $\begin{array}{l}\text { Балл } \\
\text { Score } \\
\end{array}$ & $\begin{array}{l}\text { Виды земель } \\
\text { Types of land } \\
\end{array}$ & $\begin{array}{l}\text { Площадь, га (S) } \\
\text { Area, ha (S) }\end{array}$ \\
\hline $\begin{array}{l}\text { Bысшая }\left(\mathrm{AH}_{6}\right) \\
\text { Higher }\left(\mathrm{AH}_{6}\right)\end{array}$ & 6 & $\begin{array}{l}\text { Селитебные территории } \\
\text { Residential areas }\end{array}$ & 6112,4 \\
\hline $\begin{array}{l}\text { Очень высокая }\left(\mathrm{AH}_{5}\right) \\
\text { Very high }\left(\mathrm{AH}_{5}\right)\end{array}$ & 5 & $\begin{array}{l}\text { Земли сельскохозяйственного назначения всестороннего } \\
\text { использования } \\
\text { Agricultural land for comprehensive use } \\
\text { Земли для выращивания сельскохозяйственных культур: } \\
\text { орошаемые, пахотные } \\
\text { Land used for growing crops: irrigated, arable }\end{array}$ & 7502,5 \\
\hline $\begin{array}{l}\text { Высокая }\left(\mathrm{AH}_{4}\right) \\
\text { High }\left(\mathrm{AH}_{4}\right)\end{array}$ & 4 & $\begin{array}{l}\text { Земли сельскохозяйственного назначения - для ведения } \\
\text { животноводства } \\
\text { Agricultural land used for livestock }\end{array}$ & $5417,0\left(\mathrm{~S}_{4}\right)$ \\
\hline $\begin{array}{l}\text { Средняя }\left(\mathrm{AH}_{3}\right) \\
\text { Average }\left(\mathrm{AH}_{3}\right)\end{array}$ & 3 & $\begin{array}{l}\text { Лeca, многолетние насаждения } \\
\text { Forests, perennial plantations }\end{array}$ & $5206,9(\mathrm{~S} 3)$ \\
\hline $\begin{array}{l}\text { Низкая }\left(\mathrm{AH}_{2}\right) \\
\text { Low }\left(\mathrm{AH}_{2}\right)\end{array}$ & 2 & $\begin{array}{l}\text { Лесопарковые зоны } \\
\text { Forest park zones } \\
\text { Зеленые зоны } \\
\text { Green areas }\end{array}$ & $\begin{array}{l}9517,9\left(\mathrm{~S}_{2}\right) \\
5018,6\left(\mathrm{~S}_{2}\right)\end{array}$ \\
\hline $\begin{array}{l}\text { Очень низкая }\left(\mathrm{AH}_{1}\right) \\
\text { Very low }\left(\mathrm{AH}_{1}\right)\end{array}$ & 1 & $\begin{array}{l}\text { Особо охраняемые природные территории } \\
\text { Specially protected natural areas } \\
\text { Hеиспользуемые земли (земли запаса) } \\
\text { Unused land (reserve land) }\end{array}$ & $\begin{array}{l}479,0\left(\mathrm{~S}_{1}\right) \\
45,7\left(\mathrm{~S}_{1}\right)\end{array}$ \\
\hline $\begin{array}{l}\text { Общая площадь } \\
\text { Total area }\end{array}$ & & & 49698,4 \\
\hline
\end{tabular}

Коэффициент абсолютной напряженности Ка определялся на основании данных структуры земельного фонда исследуемой территории (табл. 5) по формуле:

$$
\kappa_{\mathrm{a}}=\frac{\mathrm{AH} 6}{\mathrm{AH} 1}=11,6 .
$$

На основании полученного значения $\mathrm{K}_{\mathrm{a}}=11,6$ можно сделать вывод о нарушении равновесия между площадью земель, на которые оказывается негативное воздействие, и площадью земель, мало нарушенных или не используемых.

Для комплексного определения экологохозяйственного состояния исследуемой территории используется коэффициент относительной напряженности $K_{0}$, рассчитываемый по формуле и равный:

$$
\kappa_{0}=\frac{\mathrm{AH} 4+\mathrm{AH} 5+\mathrm{AH} 6}{\mathrm{AH} 1+\mathrm{AH} 2+\mathrm{AH} 3}=1,5 .
$$

Полученное значение показывает, что на территории ЗСО в пределах первой очереди Томского подземного водозабора повышена экологическая напряженность (система считается уравновешенной при $\left.\mathrm{K}_{0}=1\right)$ [15].

Каждой условно выделенной степени антропогенной нагрузки (АН) был присвоен весовой коэффициент: 0,8 - для площади земель $\mathrm{S}_{2}$ (категории $\mathrm{AH}_{2}$ ), 0,6 соответственно для $\mathrm{S}_{3}\left(\mathrm{AH}_{3}\right)$ и для максимальной антропогенной нагрузки $\mathrm{S}_{4}-0,4\left(\mathrm{AH}_{4}\right)$. Рассчитываем площадь земель со средо- и ресурсосберегающими функциями $\mathrm{S}_{\mathrm{c \phi}}$ :

$$
S_{c \phi}=S 1+0,8 \cdot S 2+0,6 \cdot S 3+0,4 \cdot S 4=17444,7 .
$$

В расчете не учитываем земли со степенями антропогенной нагрузки $\mathrm{AH}_{6}$ и $\mathrm{AH}_{5}$.

Коэффициент естественной защищенности (Кез) территории определяется по формуле:

$$
\mathrm{K}_{\mathrm{ez}}=\frac{\mathrm{S} 1+0,8 \cdot \mathrm{S} 2+0,6 \cdot \mathrm{S} 3+0,4 \cdot \mathrm{S} 4}{\mathrm{~S}_{\text {сум }}}=0,351 .
$$

Поскольку полученное значение коэффициента естественной защищенности $\left(K_{\text {eз }}\right)$ для исследуемой территории меньше 0,5 , можно сделать вывод о перегруженности территории хозяйственной деятельностью [15].

В результате проведенной оценки экологохозяйственного баланса территории было установлено нарушение равновесия между антропогенным воздействием и восстановительным потенциалом природных экосистем на территории Обь-Томского междуречья в пределах зон санитарной охраны Томского подземного водозабора, где сосредоточено наиболее интенсивное антропогенное воздействие, которое является следствием активного развития процессов урбанизации.

\section{Выводы}

ЗСО водозаборов устанавливаются на определенный срок. Для Томского подземного водозабора ЗСО установлены сроком на 27,4 года. За этот период может существенно увеличиться антропогенная нагрузка на территорию за счет увеличения площади населенных пунктов (рост населения влечет за собой увеличение количества бытовых отходов и объемов сточных вод), перевода земель из одной категории в другую.

Территория левого берега реки Томи характеризуется эстетической привлекательностью, экологичностью и близостью к центру города по сравнению с активно застраивающимися микрорайонами правобережья, что делает ее привлекательной для дальнейшего развития территории г. Томска. 
За исследуемый период (с 1992 г. по настоящее время) существенно увеличилась площадь населенных пунктов на территории Обь-Томского междуречья, в особенности в пределах третьего пояса ЗСО Томского подземного водозабора. При этом численность населения возросла незначительно. При освоении новых территорий следует уделять особое внимание микрорайонам, строящимся в непосредственной близости от границ $3 \mathrm{CO}$, на которых, в отличие от районов с малоэтажной застройкой, будет сосредоточено большое количество людей, автотранспорта и инженерных коммуникаций. Наглядным примером сосредоточенной техногенной нагрузки служит строящийся мкр. «Северный парк». На таких территориях необходимо уделять особое внимание созданию мероприятий, минимизирующих негативное влияние на окружающую природную среду.

В связи с увеличивающейся антропогенной нагрузкой территории в пределах ЗСО Томского подземного водозабора и наличием депрессионной воронки [2] вокруг скважин существует угроза изменения природных ландшафтов и загрязнения вод эксплуатируемого водоносного горизонта [26-28]. Дальнейшая застройка может усугубить ситуацию.

\section{СПИСОК ЛИТЕРАТУРЫ}

1. Радкау И. Природа и власть. Всемирная история окружающей среды. - М.: Изд-во. «Дом Высшей школы экономики», 2014. $-472 \mathrm{c}$.

2. Попов В.К., Лукашевич О.Д., Коробкин В.А. Экологоэкономические аспекты эксплуатации подземных вод ОбьТомского междуречья. - Томск: Изд-во Томского государственного архитектурно-строительного университета, 2003. - $174 \mathrm{c}$.

3. СанПиН 2.1.4.1110-02. Зоны санитарной охраны источников водоснабжения и водопроводов питьевого назначения. URL: http://www.consultant.ru/ (дата обращения 05.11.2018).

4. Атаев 3.В. Антропогенная трансформация ландшафтов Северо-Восточного Кавказа // Молодой ученый. - 2011. - Т. 1. № 11. - C. $105-108$.

5. Томскводоканал. URL: http://www.vodokanal.tomsk.ru/smi1737.html (дата обращения 01.11.2018)

6. Ecologization of water-land property matters on the territory of the Tom lower course / V.K. Popov et al. // IOP Conference Series: Earth and Environmental Science. - V. 33: Contemporary Issues of Hydrogeology, Engineering Geology and Hydrogeoecology in Eurasia. - 2016. - 012057. - $5 \mathrm{p}$.

7. Численность населения Российской Федерации // Сайт Федеральной службы государственной статистики. URL: https://tmsk.gks.ru/folder/37439 (дата обращения 01.11.2018).

8. Численность и размещение населения Томской области: итоги Всероссийской переписи населения 2010 года: статистический сборник № 1. - Томск: б. и., 2012. - 72 с.

9. Шалдунова Н.П., Денисова Н.С., Кирик Д.А. Математическая обработка земельно-кадастровой информации. - Пермь: Издво ФГБОУ ВПО Пермская ГСХА, 2015. - 73 с.

10. Микрорайон «Северный парк». URL: http://sever.gkkarier.ru/ (дата обращения 05.12.2018).

11. Мониторинг природной среды аэрокосмическими средствами / В.А. Малинников, А.Ф. Стеценко, А.Е. Алтынов, С.М. Попов. М.: Изд-во МИИГАиК, 2009. - 140 с

12. Сизов А.П. Мониторинг и охрана городских земель. 2-е изд., перераб. и доп. - М.: Изд-во МИИГАиК, 2009. - 264 с.

13. Мелкий В.А., Верхотуров А.А., Попова Я.П., Бурыкин А.Н. Мониторинг состояния земель и оценка динамики антропогенного воздействия на территорию Сахалина // Известия Томского политехнического университета. Инжиниринг георесурсов. - 2018. - Т. 329. - № 6. - С. 48-57.
В результате проведенной оценки экологохозяйственного баланса территории [29] было установлено нарушение равновесия между антропогенным воздействием и восстановительным потенциалом природных экосистем на территории Обь-Томского междуречья. Территория в окрестностях первой очереди Томского подземного водозабора характеризуется наибольшим антропогенным воздействием в результате интенсивного развития урбанизации. Дальнейшее развитие территории необходимо проводить с учетом рекомендаций специалистов: гидрогеологов, экологов, землеустроителей.

Таким образом, организацию мониторинга хозяйственного освоения территории в пределах зон санитарной охраны подземных водозаборов следует считать обязательным мероприятием на стадии эксплуатационной разведки подземных вод. Органы местного самоуправления должны обращать внимание на рассмотренную проблему при планировании освоения городской территории, т. к. молниеносная динамика освоения земельного фонда зачастую не может быть учтена при плановой переоценке запасов подземных вод.

14. Федеральный закон «О переводе земель или земельных участков из одной категории в другую» от 21.12.2004 N 172-Ф3. URL: http://www.consultant.ru/ (дата обращения 15.11.2018).

15. Кочуров Б.И. Экодиагностика и сбалансированное развитие. М.: Изд-во «Смоленск: Маджента», 2003. - 384 с.

16. Панченко Е.М., Дюкарев А.Г. Оценка эколого-хозяйственного баланса Обь-Томского междуречья с учетом антропогенной нагрузки // Известия Томского политехнического университета. Инжиниринг георесурсов. - 2015. - Т. 326. - № 12. - С. 87-95.

17. Ерофеев А.А., Копысов С.Г., Никифоров А.Н. Ландшафтногеофизический подход к зонированию структуры земплепользования на малом водосборе Сахалина // Известия Томского политехнического университета. Инжиниринг георесурсов. 2018. - T. 329. - № 6. - C. 39-47.

18. Van der Waal B., Rowntree K. Landscape connectivity in the upper Mzimvubu river catchment: an assessment of anthropogenic influences on sediment connectivity // Land degradation \& development. - 2018. - V. 29. - Iss. 3. - P. 713-723.

19. Седов С.Н., Александровский А.Л., Бенц М., Балабина В.И., Мишина Т.Н., Шишков В.А., Сахин Ф., Озкая В. Антропогенные отложения и почвы теллей Анатолии и Балкан: состав, генезис, связь с историей ландшафта и заселения // Почвоведение. - 2017. - № 4. - С. 387-400.

20. Mamedov R.M. Mustafayev B.N. Assessment of anthropogenic loads on landscapes as a tool to determine the potential for sustainable regional development: case study from Azerbaijan // Environment, development and sustainability. - 2007. - V. 9. Iss. 2. - P. 131-142.

21. Sapen M., Angel Ruiz L. Analysis of land use/land cover spatiotemporal metrics and population dynamics for urban growth characterization // Computers environment and urban systems. 2019. - V. 73. - P. 27-39.

22. Черных Н.А., Поповичева Л.Л. Влияние урбанизации на содержание тяжелых металлов в экосистемах юга Московской области // Агрохимия. - 2000. - № 10. - С. 62-67.

23. Drainage degradation influenced by anthropogenic load in different landscapes of the forest-steppe zone (in terms of the region of Belgorod) / M.A. Petina, A.N. Petin, Y.G. Chendev, M.G. Lebedeva, V.G. Belevantsev // Research journal of pharmaceutical, biological and chemical sciences. - 2015. V. 6. - Iss. 4. - P. 61-65.

24. Krylenko M.V, Krylenko V.V., Volkova T.A. Development prospects of natural-territorial complex of the Dolgaya spit // International Conference on Maritime Spatial Planning, Ecosystem 
Approach and Supporting Information Systems (MaPSIS). - Las Palmas de Gran Canaria, Spain, 2017. - V. 166. - P. 98-102.

25. Qiu Z., Kennen J.G., Giri S. Reassessing the relationship between landscape alteration and aquatic ecosystem degradation from a hydrologically sensitive area perspective // Science of the total environment. - 2019. - V. 650. - P. 2850-2862.

26. Попов В.К. Вода. Природа. Власть // Проблемы геологии и освоения недр: Труды ХХ Международного научного симпозиума имени академика М.А. Усова студентов и молодых ученых. - Томск, Россия, 2016. - Т. 1. - С. 513-514.

27. Hydrogenous mineral neoformations in Tomsk water intake facility from underground sources / E.M. Dutova et al. // IOP Conference Series: Earth and Environmental Science. - V. 33:
Contemporary Issues of Hydrogeology, Engineering Geology and Hydrogeoecology in Eurasia. - 2016. - 012017. - 6 p.

28. Трехмерная визуализация неблагоприятных природных условий для корректировки кадастровой стоимости / Е.И. Аврунев, Н.В. Гатина, М.В. Козина, В.К. Попов // Известия Томского политехнического университета. Инжиниринг георесурсов. 2019. - T. 330. - № 1. - C. 181-190.

29. Neef E. Die Stellung der Landschaftsokologie in der phyisischen Geographie // Geographische Berichte. - 1962. - V. 4. - S. 349-356.

Поступила 11.02.2019 2.

\section{Информация об авторах}

Попов В.К., доктор геолого-минералогических наук, профессор отделения геологии Инженерной школы природных ресурсов Национального исследовательского Томского политехнического университета.

Пасечник Е.Ю., кандидат геолого-минералогических наук, доцент отделения геологии Инженерной школы природных ресурсов Национального исследовательского Томского политехнического университета.

Чилингер Л.Н., аспирант отделения геологии Инженерной школы природных ресурсов Национального исследовательского Томского политехнического университета.

Аврунев Е.И., кандидат технических наук, доцент кафедры кадастра и территориального планирования Сибирского государственного университета геосистем и технологий.

Редькина В.И., магистр отделения геологии Инженерной школы природных ресурсов Национального исследовательского Томского политехнического университета. 
UDC 628.14:556.3(24):504.064(571.16)

\title{
MONITORING OF ECONOMIC DEVELOPMENT WITHIN THE BOUNDS OF UNDERGROUND WATER INTAKE PROTECTIVE SANITARY ZONE TERRITORY (BY THE EXAMPLE OF TOMSK UNDERGROUND WATER INTAKE LINE)
}

\author{
Viktor K. Popov $^{1}$ \\ Elena Yu. Pasechnik1, \\ paseyu@yandex.ru \\ Liliya N. Chilinger ${ }^{1}$, \\ lilichilinger@gmail.com \\ Evgeny l. Avrunev², \\ avrynev_ei@ngs.ru \\ Veronika I. Redkina ${ }^{1}$, \\ V_red96@mail.ru \\ 1 National Research Tomsk Polytechnic University, \\ 30, Lenin avenue, Tomsk, 634050, Russia. \\ 2 Siberian State University of Geosystems and Technologies, \\ 10, Plakhotny street, Novosibirsk, 630108, Russia.
}

Relevance. Sanitary protection zones of underground water intakes are established to protect the groundwater of operational aquifers from various types of pollution for the estimated depreciation period of its operation. After this period or with a significant change in the intensity of water withdrawal, reassessment of reserves and, if necessary, correction of the boundaries of the sanitary protection zones are carried out.

Based on the project documentation for the sanitary protection zones of sources of underground drinking water supply, they are entered into the State Register of Real Estate, and the determined settlement boundaries are coordinated with the center of state sanitary and epidemiological supervision. Despite the fact that water intake is a strategically important object, the need to take into account the borders in the register appeared only in relation to the entry into force of the Federal Law No. 221-FZ in 2007. Currently, for all types of zones with special conditions for the use of the territory, the deadline for entering the required information in the State Register of Real Estate is January 1, 2022. Thus, from the moment of calculating the boundaries of the Sanitary protection zones to their establishment and introduction of information, a long period of time passes, during which the anthropogenic load can often change (the area of settlements increases, new engineering infrastructure objects appear) in areas with limited land use. In this regard, it is necessary to organize monitoring of economic activities within the Sanitary protection zones of underground water intakes. In such areas, it is necessary to assess and predict changes in the components of the natural environment under the influence of anthropogenic pressure in order to obtain reliable information about the state of the land and how to ensure rational land use.

The aim of the research is to reveal the possibilities of monitoring the dynamics of economic development of the territory within the sanitary protection zones of the first stage of the Tomsk underground water intake.

Methods: cartometric research based on geo-information technologies, statistical and correlation and regression analyzes, geoinformation analysis, landscape analysis method.

Results. The article presents the results of studies of the dynamics and nature of changes in the anthropogenic load within the sanitary protection zone of the central part of the first stage of the Tomsk underground water intake. The basis of the actual material is the data of the Federal Service for State Registration, Cadastre and Cartography of the Tomsk Region, the spatial data banks of Esri maps internetresource, which form the basis of a cartometric analysis of forest areas and borders of residential areas. The authors revealed the trends in the area of various types of landscapes and the boundaries of settlements within the study area. Landscapes of this territory are subject to changes in the development of land use and water use. Residential load in 2018 is relatively small, its increase occurs mainly due to individual housing and country house construction, and not multi-storey buildings. The authors estimated the current population size, forecasted its change for the near future and revealed the increase in residential areas in individual settlements.

Conclusions. It was established that within the third belt of the sanitary protection zones of the first line of the Tomsk underground water intake and on the adjacent territory, the anthropogenic load on the environment significantly increased during the period under study due to the growth in the area of settlements. The increase was due to the development of sites for individual housing construction, which may lead to pollution of aquifers due to improperly equipped individual drainage systems. It is shown that near the existing border of the sanitary protection zones, multi-storey buildings are actively being conducted, which can generally have a negative impact on the state of individual landscape elements, including groundwater. Thus, on the example of the Tomsk underground water intake, the main conclusion was drawn that it is necessary to organize and conduct monitoring of the economic development of the territory within the zones of sanitary protection of underground water intakes. It is required to adjust the procedural issues of entering information into the State Register of Real Estate in brief.

Key words:

Protective sanitary zones, human impact, remote sensing, monitoring, landscape, population. 


\section{REFERENCES}

1. Radkau I. Priroda i vlast. Vsemirnaya istoriya okruzhayushchey sredy [Nature and power. World history of the environment]. Moscow, Dom Vysshey shkoly ehkonomiki Publ., 2014. 472 p.

2. Popov V.K., Lukashevich O.D., Korobkin V.A. Ekologoekonomicheskie aspekty ekspluatatsii podzemnykh vod ObTomskogo mezhdurechya [Ecological and economic aspects of groundwater exploitation of the Ob-Tomsk interfluve]. Tomsk, Tomsk State university of architecture and building Publ. house, 2003. $174 \mathrm{p}$.

3. SanPiN 2.1.4.1110-02. Zony sanitarnoy okhrany istochnikov vodosnabzheniya $i$ vodoprovodov pitevogo naznacheniya [Sanitary protection zones of water supply sources and drinking water sup ply systems]. Available at: http://www.consultant.ru/ (accessed 5 November 2018).

4. Ataev Z.V. Antropogennaya transformatsiya landshaftov SeveroVostochnogo Kavkaza [Anthropogenic transformation of landscapes of the North-Eastern Caucasus]. Molodoy ucheny, 2011, vol. 1, Iss. 11, pp. 105-108

5. Tomskvodokanal [Tomskvodokanal]. Available at: http://www.vodokanal.tomsk.ru/smi-1737.html (accessed 5 November 2018).

6. Popov V.K. Ecologization of water-land property matters on the territory of the Tom lower course. IOP Conference Series: Earth and Environmental Science. Vol. 33: Contemporary Issues of Hydrogeology, Engineering Geology and Hydrogeoecology in Eurasia, 2016, $5 \mathrm{p}$

7. Chislennost naseleniya Rossiyskoy Federatsii [Population of the Russian Federation]. Federalnaya sluzhba gosudarstvennoy statistiki [Federal State Statistics Service]. Available at https://tmsk.gks.ru/folder/37439 (accessed 5 November 2018).

8. Chislennost $i$ razmeshchenie naseleniya Tomskoy oblasti: itogi Vserossiyskoy perepisi naseleniya 2010 goda: statisticheskiy sbornik № 1 [Population size and distribution of the Tomsk region: results of the 2010 All-Russian Population Census: statistical compendium]. Tomsk, 2012. 72.

9. Shaldunova N.P., Denisova N.S., Kirik D.A. Matematicheskaya obrabotka zemelno-kadastrovoy informatsii [Mathematical processing of land cadastral information. Perm, FSBEI HPE Perm State Agricultural Academy Publ. house, 2015. 73 p

10. Mikrorayon «Severny park» [Microdistrict «Severny park»]. Available at: http://sever.gkkarier.ru/ (accessed 5 November 2018).

11. Malinnikov V.A., Stectsenko A.F., Altynov A.E., Popov S.M Monitoring prirodnoy sredy aerokosmicheskimi sredstvami [Monitoring the natural environment by aerospace means]. Moscow, MIIGAiK Publ., 2009. $140 \mathrm{p}$

12. Sizov A.P. Monitoring i okhrana gorodskikh zemel [Monitoring and protection of urban land]. Moscow, MIIGAiK Publ., 2009. $264 \mathrm{p}$.

13. Melkiy V.A., Verkhoturov A. A., Popova Y.P. Monitoring of land status and assessment of dynamics of anthropogenic impact on the territory of Sakhalin. Bulletin of the Tomsk polytechnic university. Geo assets engineering, 2018, vol. 329, no. 6, pp. 48-57. In Rus.

14. Federalny zakon $« O$ perevode zemel ili zemelnykh uchastkov iz odnoy kategorii v druguyu» [On the transfer of land or land from one category to another. Federal Law]. 21.12.2004 No. 172-FZ. Available at: http://www.consultant.ru/ (accessed 5 November 2018).

15. Kochurov B.I. Ekodiagnostika i sbalansirovannoe razvitie [Ecodiagnostics and balanced development]. Moscow, Smolensk: Magenta Publ., 2003. 384 p.

16. Panchenko E.M., Dyukarev A.G. Assessment of the ecological and economic balance of the Ob-Tomsk interfluve with allowance for anthropogenic load. Bulletin of the Tomsk Polytechnic University. Geo Assets engineering, 2015, vol. 326, no. 12, pp. 87-95. In Rus.

17. Erofeev A.A., Kopysov S.G., Nikiforov A.N. Landscapegeophysical approach to zoning the structure of land use in the small catchment area of Sakhalin. Bulletin of the Tomsk Polytechnic University. Geo Assets engineering, 2018, vol. 329, no. 6, pp. 39-47. In Rus.

18. Van der Waal B., Rowntree K. Landscape connectivity in the upper Mzimvubu river catchment: an assessment of anthropogenic influences on sediment connectivity. Land degradation \& development, 2018, vol. 29, no. 3, pp. 713-723.

19. Sedov S.N., Aleksandrovskii A.L., Benz M. Anthropogenic sediments and soils of tells of the Balkans and Anatolia: Composition, genesis, and relationships with the history of landscape and human occupation. Eurasian soil science, 2017, V.50, Iss. 4, pp. 373-386.

20. Mamedov R.M.L, Mustafayev B.N.H. Assessment of anthropogenic loads on landscapes as a tool to determine the potential for sustainable regional development: case study from Azerbaijan. Environment, development and sustainability, 2007, vol. 9, Iss. 2, pp. 131-142.

21. Sapen M., Angel Ruiz L. Analysis of land use/land cover spatiotemporal metrics and population dynamics for urban growth characterization. Computers environment and urban systems, 2019, vol. 73, pp. 27-39.

22. Chernykh N.A., Popovicheva L.L. The effect of urbanization on the content of heavy metals in the ecosystems of the southern Moscow oblast. Agricultural chemistry, 2000, no. 10, pp. 62-67.

23. Petina M.A., Petin A.N., Chendev Y.G., Lebedeva M.G., Belevantsev V.G. Drainage degradation influenced by anthropogenic load in different landscapes of the forest-steppe zone (in terms of the region of Belgorod). Research journal of pharmaceutical, biological and chemical sciences, 2015, V.6, Iss. 4, pp. 61-65.

24. Krylenko M.V., Krylenko, V.V., Volkova T.A. Development prospects of natural-territorial complex of the Dolgaya spit. International Conference on Maritime Spatial Planning, Ecosystem Approach and Supporting Information Systems (MaPSIS). Las Palmas de Gran Canaria, Spain, 2017. Vol. 166, pp. 98-102.

25. Qiu Z., Kennen J.G., Giri S. Reassessing the relationship between landscape alteration and aquatic ecosystem degradation from a hydrologically sensitive area perspective. Science of the total, 2019, vol. 650, pp. 2850-2862.

26. Popov V.K. Voda. Priroda. Vlast [Water. Nature. Power]. Trudy XX Mezhdunarodnogo nauchnogo simpoziuma imeni akademika M.A. Usova studentov i molodykh uchenykh. Problemy geologii $i$ osvoeniva nedr [Proc. of the XX International Academic Symposium named after MA. Usov students and young scientists. Problems of geology and exploration of mineral resources]. Tomsk, Russia, 2016. Vol. 1, pp. 513-514.

27. Dutova E.M. Hydrogenous mineral neoformations in Tomsk water intake facility from underground sources. IOP Conference Series: Earth and Environmental Science, 2016, vol. 33. Contemporary Issues of Hydrogeology, Engineering Geology and Hydrogeoecology in Eurasia, 012017, 6 p.

28. Avrunev E.I., Gatina N.V., Kozina M.V., Popov V.K. 3D visualization of adverse natural conditions for adjustment of land cadastral value. Bulletin of the Tomsk Polytechnic University. Geo Assets Engineering, 2019, vol. 330, no. 1, pp. 181-190. In Rus.

29. Neef E. Die Stelung der Landschaftsokologie in der phyisischeh Geographie [The Stelung of the landscape ecology in the physical geography]. Geographische Berichte, 1962, vol. 4, pp. 349-356. In Germ.

Received: 11 February 2019.

\section{Information about the authors}

Viktor K. Popov, Dr. Sc., professor, National Research Tomsk Polytechnic University.

Elena Yu. Pasechnik, Cand. Sc., associate professor, National Research Tomsk Polytechnic University.

Liliya N. Chilinger, postgraduate, National Research Tomsk Polytechnic University.

Evgeny I. Avrunev, Cand. Sc., associate professor, Siberian State University of Geosystems and Technologies.

Veronika I. Redkina, graduate student, National Research Tomsk Polytechnic University. 